\title{
Concentrated Solar Thermal Steam Cooking System: An Application in DTU Hostel
}

\author{
Vikas kumar tomar, RajeshKumar, J P Kesari
}

\begin{abstract}
Feasibility study of Concentrated Solar Thermal Steam Cooking System has performed for climatic conditions of Delhi by taking the case of DTU boys hotel mess to replace LPG cooking system. Energy requirement for mass cooking in DTU mess is calculated to be $288981 \mathrm{KWh}$ which till now is fulfilled by 15 LPG cylinders each of capacity of $14 \mathrm{~kg}$. An attempt is made to fulfill this requirement with solar energy using Scheffler Dish, although it is also known that complete energy requirement cannot be fulfilled due to unavailability of solar radiations at night, in monsoon and sometimes in winter. Almost $50 \%$ of energy requirement i.e.143880 $\mathrm{KWh}$ can meet by this system using 25 Scheffler Dish of 16m2. Calculations for CO2 emission due to burning of LPG in DTU hostel mess is also done which comes out to be 189 tonne and it is shown that with implementation of such a cooking system almost $50 \%$ of $\mathrm{CO} 2$ emission can be controlled. Effect of DNI, optical efficiency and temperature difference of feed water and steam is shown in this work. Cost of this project that is bear by DTU is around 62 lakhs with payback period of 2.84 years. This system has proposed with keeping in mind that it could prove a model to encourage other institutions in Delhi for implementing this technology for mass and collective cooking.
\end{abstract}

Keywords: Scheffler Dish; Collective cooking;Performance; Efficiency;Incident angle modifier; Cosine loses;

\section{INTRODUCTION}

Kalogirou et al [1] analyzed the environmental problems related to the use of conventional sources of energy and outlined the benefits offered by renewable energy systems. Dafle et al [2] evaluate the Design, Fabrication and Performance of 2 bar pressure and $110^{\circ} \mathrm{C}$ temperature cooking application using $16 \mathrm{~m}^{2}$ Scheffler reflectors. During the performance it was observed that solar radiation over the day varies from $620 \mathrm{~W} / \mathrm{m}^{2}$ to $937 \mathrm{~W} / \mathrm{m}^{2}$. The instantaneous efficiency decreases with increase in radiation. Absorber plate temperature varies from $138^{\circ} \mathrm{C}$ to $235^{\circ} \mathrm{C}$, while maximum steam temperature achieved was $107^{\circ} \mathrm{C}$ at the outlet of the boiler. The overall efficiency achieved was $57.41 \%$ which appears on higher side as compared to parabolic trough devices. Kashyap et al [3] designed Scheffler reflector to supply sufficient heat energy to the crematorium by concentrating solar energy. Mangesh et al [4] studied the performance of $2.7 \mathrm{~m}^{2}$ Scheffler reflector and uses 10 liter of water for experiment. Performance analysis of the reflector revealed that average power and efficiency in terms

Revised Manuscript Received on September 25, 2019

Vikas kumar tomar, Delhi Technological University, Bawana Road, New Delhi-110042, India

RajeshKumar, Delhi Technological University, Bawana Road, New Delhi-110042, India

JPKesari, Delhi Technological University, Bawana Road, New Delhi-110042, India of water boiling tests to be 550W and $19 \%$. Wu et al [5] proposed a parabolic dish/AMTEC solar thermal power system that is a combined system in which a parabolic dish solar collector is cascaded with an alkali metal thermal to electric converter (AMTEC) through a coupling heat exchanger.

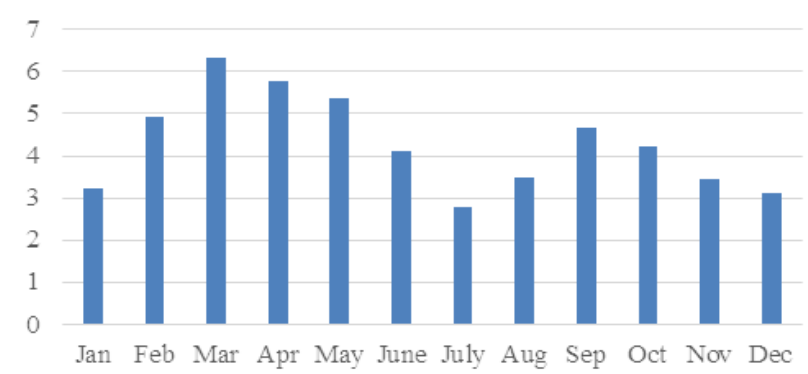

Figure 1. Monthly DNI for Delhi in (kWh/m²/Day)

Reddy et al [6] presented techno-economic feasibility of a $5 \mathrm{MWe}$ solar parabolic dish collector field for entire India covering 58 locations. A graph of monthly DNI for Delhi is shown in Figure.

\section{OBJECTIVES OF THE PRESENT WORK}

Following work has done by keeping in mind the requirement of clean and renewable source of energy in almost every field of production. To check the requirement and feasibility of proposed system, given below objectives are fulfilled in this work:

o study the basic design and principle of working Scheffler dish system and propose the required P\&I layout for steam cooking plant in DTU.

o calculate the total collector surface area of Scheffler dish required according to thermal energy demand that can be fulfilled using this system.

$\bullet$

o calculate the useful output thermal energy that can be extracted and system efficiency using required relations and to study the effect of some other parameters on performance of system.

-

o calculate the amount of $\mathrm{CO}_{2}$ emit per annum due to burning of LPG for cooking.

o check the economic feasibility of steam cooking system in DTU under climate conditions of Delhi and to calculate the payback period of system.

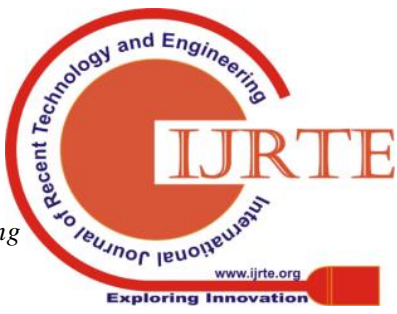




\section{P \& I DIAGRAM OF STEAM COOKING SYSTEM}

- The entire design and layout for proposed system also known as P\&I diagram is shown in fig 1. Piping system has shown with blue color for incoming feed water and red color pipe shows steam flow. Various hand operated gate valves and gauges are also shown. This is basic layout for any steam cooking plant and number of Scheffler dish will increase or decrease according to size of plant and required energy demand. This system is interconnected with an electric steam generator for steam generation during morning and rainy season. In place of electricity other means like LPG boiler or boiler using briquettes for steam generation can also be used.

\section{Performance ANALYSIS OF SySTEM}

$\frac{\mathbb{Q}}{A_{P}}=D N I \times \eta 0 \times \operatorname{Cos} \theta \times K \theta_{L}-a_{1} \times\left(T_{m}-\right.$

- $\left.T_{a}\right)-a_{2} \times\left(T_{\mathrm{m}}-T_{a}\right)^{2}$

where,

DNI $=$ Direct Normal Irradiance $\left(\mathrm{W} / \mathrm{m}^{2}\right)$

$\theta=$ Angle of incidence

$\mathrm{a}_{1}=$ First degree temperature dependence heat loss coefficient for conduction and convection $\left(\mathrm{w} / \mathrm{m}^{2} \mathrm{k}\right)$. $\mathrm{a}_{2}=$ Second degree temperature dependence heat loss coefficient for radiation $\left(\mathrm{w} / \mathrm{m}^{2} \mathrm{k}\right)$.

$\mathrm{K} \theta_{\mathrm{L}}=$ Longitudinal incidence angle modifier

- Optical efficiency, $\eta_{0}=\gamma \cdot \rho \cdot \alpha . \Gamma$

where,

$\gamma=$ Intercept factor

$\rho=$ Reflectivity of reflector surface

$\alpha=$ Absorptance of the receiver

$\Gamma=$ Transmittance of glass cover of receiver $=1$.

$$
\begin{aligned}
& \eta=\frac{\text { DNIsmoscosi }-\mathrm{al}(\mathrm{Tm}-\mathrm{Ia})+\mathrm{a} 2(\mathrm{Im}-\mathrm{Ta}) 2}{\mathrm{DND}} \\
& \eta=\eta 0 x \cos \theta-\frac{\mathrm{a}(\mathrm{Tm}-\mathrm{Ta})}{\mathrm{DNI}}-\frac{\mathrm{a2}(\mathrm{Tm}-\mathrm{Ta}) 2}{\mathrm{DND}}
\end{aligned}
$$

Efficiency relation for Parabolic Dish collector is: $\frac{I=D N I \times r 0-a 1(T m-T a)+a 2(\mathrm{Tm}-\mathrm{Ta}) 2}{\mathrm{DNI}}$
- Cosine loss $(\cos \theta)$

where,

$$
\text { , } \cos \theta=\cos \left(43.23^{\circ}\right. \text {-solar declination }
$$

$$
\partial=23.45 \sin [2 \Pi(284+n) / 36.25]
$$

$$
\mathrm{n}=\text { day of year. }
$$

- Incident Angle Modifier $\mathrm{K} \theta_{\mathrm{L}}$

$$
\mathrm{K} \theta_{\mathrm{L}}=\eta_{\mathrm{o}}(\theta) / \eta_{\mathrm{o}}\left(\text { on } 22^{\text {nd }} \text { December }\right)
$$

for making calculation simple, we have taken unit incident angle modifier.

- Thermal Energy Loss

Conduction, Convection and Radiation losses are the reason of decreasing efficiency of the system. These losses increase with increase in temperature difference. To minimize these losses receiver should be covered with thermal insulator. To increase absorption of receiver, it should be painted with blackboard paint [8].

Thermal Energy Losses $=a_{1}\left(T_{m}-T_{a}\right)+a_{2}\left(T_{m}-T_{a}\right)^{2}$

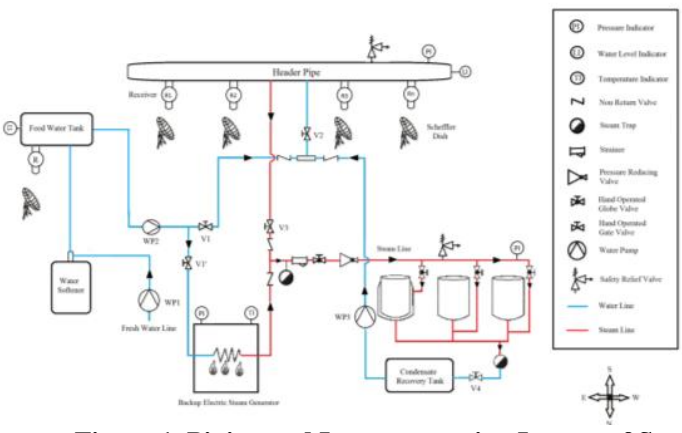

Figure 1. Piping and Instrumentation Layout of Steam Cooking System Cooking System

\section{EFFICIENCY}

It is the overall efficiency of a system using Scheffler Dish as the collector. A more efficient substitute of Scheffler Dish is Parabolic Dish collector but it also has some limitations.

$$
\eta=\text { output energy/ input energy }
$$

Above relation [8] shows that Parabolic Collectors are free from cosine losses which result in more efficient performance of the system. Theoretical analysis of this system has been done for different parameters by changing the values one by one. Table1\&2 shows the performance analysis for different parameters in detail.

Table 1 calculation for energy loss due to conduction, convection and radiation 


\begin{tabular}{|c|c|c|c|c|c|c|c|c|c|c|}
\hline \multirow[t]{2}{*}{ S.No. } & \multirow[t]{2}{*}{ Month } & \multirow{2}{*}{$\begin{array}{c}\text { DNI(W } \\
\left./ \mathbf{m}^{2}\right)\end{array}$} & \multirow[t]{2}{*}{$\eta_{0}$} & \multirow[t]{2}{*}{$\operatorname{Cos} \theta$} & \multirow{2}{*}{$\begin{array}{l}a_{1}(W / \\
\left.\mathbf{m}^{2} K\right)\end{array}$} & \multirow{2}{*}{$\begin{array}{c}\mathbf{a}_{2} \\
\left(\mathbf{W} / \mathbf{m}^{2}\right. \\
\mathbf{K})\end{array}$} & \multicolumn{4}{|c|}{ Energy loss $\left(\mathrm{W} / \mathrm{m}^{2}\right)$} \\
\hline & & & & & & & $\begin{array}{c}\Delta \mathrm{T}_{1}= \\
90^{\circ}\end{array}$ & $\begin{array}{c}\Delta \mathrm{T}_{2}= \\
100^{\circ}\end{array}$ & $\begin{array}{r}\Delta \mathrm{T}_{3}= \\
110^{\circ}\end{array}$ & $\begin{array}{r}\Delta \mathrm{T}_{4}= \\
120^{\circ}\end{array}$ \\
\hline 1 & JAN & 405 & .65 & .8289 & 1.2 & .001 & 116 & 130 & 144 & 158 \\
\hline 2 & FEB & 615 & .65 & .8350 & 1.2 & .001 & 116 & 130 & 144 & 158 \\
\hline 3 & MAR & 790 & .65 & .8398 & 1.2 & .001 & 116 & 130 & 144 & 158 \\
\hline 4 & APR & 724 & .65 & .8440 & 1.2 & .001 & 116 & 130 & 144 & 158 \\
\hline 5 & MAY & 673 & .65 & .8476 & 1.2 & .001 & 116 & 130 & 144 & 158 \\
\hline 6 & JUNE & 516 & .65 & .8500 & 1.2 & .001 & 116 & 130 & 144 & 158 \\
\hline 7 & JULY & 350 & .65 & .8518 & 1.2 & .001 & 116 & 130 & 144 & 158 \\
\hline 8 & AUG & 438 & .65 & .8525 & 1.2 & .001 & 116 & 130 & 144 & 158 \\
\hline 9 & SEP & 584 & .65 & .8523 & 1.2 & .001 & 116 & 130 & 144 & 158 \\
\hline 10 & OCT & 530 & .65 & .8512 & 1.2 & .001 & 116 & 130 & 144 & 158 \\
\hline 11 & $\mathrm{NOV}$ & 431 & .65 & .8490 & 1.2 & .001 & 116 & 130 & 144 & 158 \\
\hline 12 & DEC & 390 & .65 & .8462 & 1.2 & .001 & 116 & 130 & 144 & 158 \\
\hline
\end{tabular}

Table 2. Input and Output Energy with Efficiency of system at different $\Delta \mathrm{T}$

\begin{tabular}{|c|c|c|c|c|c|c|c|c|c|c|}
\hline \multirow[t]{2}{*}{ S. No. } & \multirow[t]{2}{*}{ Month } & \multirow[t]{2}{*}{ DNI*(W/m $\left.{ }^{2}\right)$} & \multicolumn{4}{|c|}{ Output(W/m²) } & \multicolumn{4}{|c|}{$\eta$} \\
\hline & & & $\mathrm{E}_{1}$ & $\overline{E_{2}}$ & $\mathrm{E}_{3}$ & $\mathrm{E}_{4}$ & $\eta_{1}$ & $\eta_{2}$ & $\eta_{3}$ & $\eta_{4}$ \\
\hline 1 & JAN & 405 & 102 & 89 & 75 & 60 & 25 & 22 & 18.3 & 15 \\
\hline 2 & FEB & 615 & 218 & 204 & 190 & 176 & 36 & 33.1 & 31 & 25.7 \\
\hline 3 & MAR & 790 & 315 & 301 & 287 & 273 & 40 & 38 & 36.3 & 34.5 \\
\hline 4 & APR & 724 & 281 & 267 & 253 & 239 & 39 & 37 & 35 & 33 \\
\hline 5 & MAY & 673 & 255 & 241 & 227 & 213 & 38 & 35.8 & 33.7 & 31.6 \\
\hline 6 & JUNE & 516 & 170 & 156 & 142 & 128 & 33 & 30.2 & 27.5 & 24.8 \\
\hline 7 & JULY & 350 & 77 & 63 & 49 & 35 & 22 & 18 & 14 & 10 \\
\hline 8 & AUG & 438 & 126 & 112 & 98 & 84 & 29 & 25.6 & 22.3 & 19.2 \\
\hline 9 & SEP & 584 & 207 & 193 & 179 & 165 & 36 & 33 & 30.7 & 28.2 \\
\hline 10 & OCT & 530 & 177 & 163 & 149 & 135 & 33 & 31 & 28 & 25.5 \\
\hline 11 & NOV & 431 & 122 & 108 & 94 & 80 & 28 & 25 & 21.8 & 18.6 \\
\hline 12 & DEC & 390 & 99 & 85 & 71 & 57 & 26 & 21.8 & 18.2 & 14.6 \\
\hline
\end{tabular}

\section{ECONOMICS OF PROPOSED DTU PLANT}

After proposing the steam cooking plant consist of 25 Scheffler dish of $16 \mathrm{~m}^{2}$ for DTU boys hostel mess, we discuss the economic feasibility of Steam Cooking System in terms of input solar radiations and the payback period of plant. Total annual energy required for cooking and the potential of Steam Cooking Plant to share the load is calculated.

6.1 Total energy requirement for cooking

Annual thermal energy demand of boys hostel mess in DTU is calculated by multiplying number of dish cooked per day with number of working days in month and also with thermal energy required for one dish. Thermal energy required for one dish is calculated by dividing the net thermal energy used for cooking in one day with total number of dish prepared in one day. Following table represents the monthly thermal energy required by mess in $\mathrm{KWh}$

DTU hostel mess works 365 days in a year. It closed only at night of Friday of every week. In summer vacations of June and July only one mess remains working due to decrease in strength of students. Thermal energy requirement for each dish is calculated to be just $0.33 \mathrm{KWh}$. Thermal energy requirement in month of June and July is minimum and it goes in favour of the proposed plant as average DNI in month of June and July is very low. Total annual thermal energy requirement is also calculated which comes out to be 288981 KWh.
Table 3. Monthly Requirement of Energy for Cooking

\begin{tabular}{ccccc}
\hline Month & $\begin{array}{c}\text { No of } \\
\text { working } \\
\text { days of } \\
\text { mess }\end{array}$ & $\begin{array}{c}\text { Thermal } \\
\text { energy } \\
\text { required per } \\
\text { dish(KWh) }\end{array}$ & $\begin{array}{c}\text { Number of } \\
\text { dish cooked } \\
\text { per day }\end{array}$ & $\begin{array}{c}\text { Monthly } \\
\text { thermal units } \\
\text { required for } \\
\text { mess(KWh) }\end{array}$ \\
\hline Jan & 31 & 0.33 & 2700 & 27621 \\
Feb & 28 & 0.33 & 2700 & 24948 \\
Mar & 31 & 0.33 & 2700 & 27621 \\
April & 30 & 0.33 & 2700 & 26730 \\
May & 31 & 0.33 & 2700 & 27621 \\
June & 30 & 0.33 & 900 & 8910 \\
July & 31 & 0.33 & 900 & 9207 \\
Aug & 31 & 0.33 & 2700 & 27621 \\
Sep & 30 & 0.33 & 2700 & 26730 \\
Oct & 31 & 0.33 & 2700 & 27621 \\
Nov & 30 & 0.33 & 2700 & 26730 \\
Dec & 31 & 0.33 & 2700 & 27621 \\
\hline Total & 365 & & & 288981 \\
\hline
\end{tabular}

6.2 Estimation of potential of DTU steam cooking system

Energy potential of one dish is calculated by multiplying the average DNI with the overall efficiency of the system and with the surface area of the one dish. Monthly average DNI for Delhi is $4.29 \mathrm{KWh} / \mathrm{m}^{2} /$ day. Rated thermal output for one Scheffler Dish of $16 \mathrm{~m}^{2}$ is $5.5 \mathrm{KW}$ but it is not considered in proposed design as this value changes from place to place and depends upon the DNI of that place. Monthly thermal units generated by one Scheffler dish of $16 \mathrm{~m}^{2}$ are calculated to be $7428 \mathrm{KWh}$. As total 25 dishes are present in proposed design the total thermal output will be $185688 \mathrm{KWh}$. Table 4. shows the energy estimation potential of every month by the plant. Result of the table is 


\section{Concentrated Solar Thermal Steam Cooking System: An Application in DTU Hostel}

represent in the graphical form with month on $\mathrm{X}$-axis and thermal energy output on $\mathrm{Y}$-axis. Energy generation remains maximum for March then starts decreasing and reaches to minimum in July. A number of days for which sun radiations are available is not constant. The thermal output curve is also compared with the DNI curve on the same graph and follows the same pattern as shown by DNI curve. It signifies that the thermal output of Scheffler Dish depends upon the DNI. As data for monthly thermal unit required for cooking and for the monthly thermal unit generated by the Steam plant has been calculated, solar fraction can be calculated which is defined as the thermal unit generated by plant to the thermal unit required by the process. The annual average solar fraction comes out to be around $50 \%$.

Table 4. Monthly Energy Estimation Potential of Proposed Plant

\begin{tabular}{|c|c|c|c|c|c|}
\hline $\begin{array}{c}\text { Mon } \\
\text { th }\end{array}$ & $\begin{array}{c}\text { DNI } \\
\left(\mathrm{KWh} / \mathbf{m}^{2} /\right. \\
\text { Day) }\end{array}$ & $\begin{array}{c}\text { No. of } \\
\text { Days } \\
\text { Solar } \\
\text { radiatio } \\
\mathbf{n} \\
\text { availabl } \\
\text { e } \\
\end{array}$ & $\begin{array}{c}\text { Thermal } \\
\text { Output } \\
\text { Energy per } \\
\text { Dish } \\
\text { (KWh/m²/ } \\
\text { Day) }\end{array}$ & $\begin{array}{c}\text { Monthly } \\
\text { Thermal } \\
\text { Unit } \\
\text { generated } \\
\text { by } 1 \text { Dish } \\
\text { (KWh) }\end{array}$ & $\begin{array}{c}\text { Monthly } \\
\text { Thermal } \\
\text { Unit } \\
\text { generated } \\
\text { by 25 } \\
\text { Dish } \\
\text { (KWh) }\end{array}$ \\
\hline Jan & 3.24 & 15 & 0.97 & 232.8 & 5820 \\
\hline Feb & 4.92 & 20 & 1.287 & 411.84 & 10296 \\
\hline Mar & 6.32 & 28 & 1.896 & 849.4 & 21235 \\
\hline Apr & 5.79 & 28 & 1.737 & 778 & 19454 \\
\hline May & 5.38 & 28 & 1.614 & 723 & 18077 \\
\hline June & 4.13 & 25 & 1.239 & 496 & 12390 \\
\hline July & 2.79 & 12 & 0.837 & 160.7 & 4017.6 \\
\hline Aug & 3.5 & 20 & 1.05 & 336 & 8400 \\
\hline Sep & 4.67 & 27 & 1.401 & 605 & 15131 \\
\hline Oct & 4.24 & 25 & 1.272 & 509 & 12720 \\
\hline Nov & 3.45 & 25 & 1.035 & 414 & 10350 \\
\hline \multirow[t]{2}{*}{ Dec } & 3.12 & 16 & 0.936 & 240 & 5990 \\
\hline & & & Total & 5755.74 & 143880.6 \\
\hline
\end{tabular}
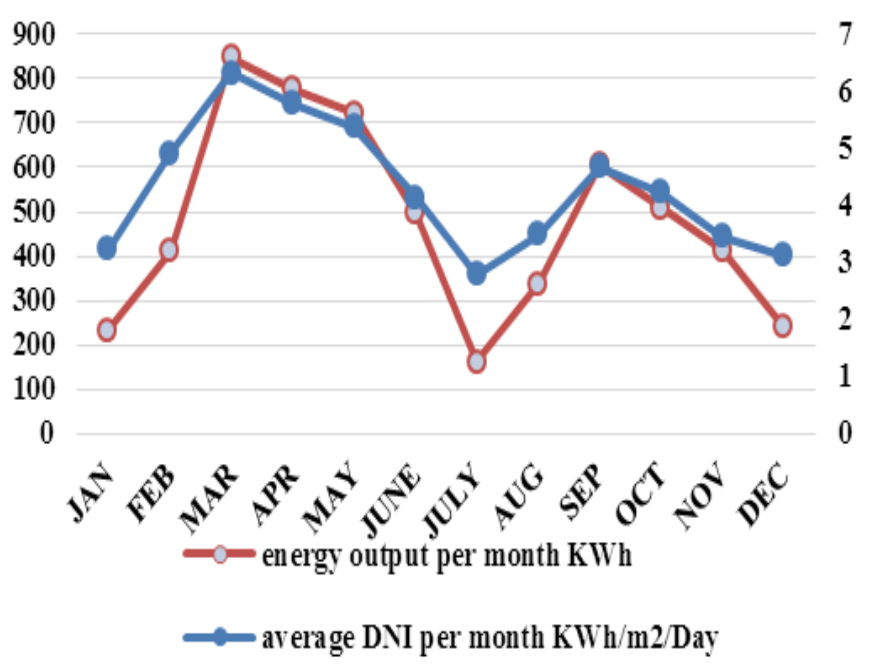

Figure 2. Monthly Thermal energy Output and DNI for DTU plant

\begin{tabular}{|c|c|c|}
\hline $\begin{array}{l}\text { S. } \\
\text { No. }\end{array}$ & Design Parameter Description & Value \\
\hline 1. & Type of fuel & LPG \\
\hline 2. & Number of LPG cylinder used per day & 15 \\
\hline 3. & Cost of one cylinder & 800 \\
\hline 4. & Fuel cost for one day cooking & $12000 \mathrm{INR}$ \\
\hline 5. & Cost of fuel in one year & 43.8 Lakhs \\
\hline 6. & $\begin{array}{l}\text { Percentage of fuel save by Steam } \\
\text { Cooking System }\end{array}$ & $50 \%$ \\
\hline 7. & Money save in one year & 21.9 Lakhs \\
\hline 8. & $\begin{array}{l}\text { Cost of Scheffler Dish per } \mathrm{m}^{2} \text { according to } \\
\text { MNRE standards }\end{array}$ & $18000 / \mathrm{m}^{2}$ \\
\hline 9. & Cost of one Scheffler Dish of $16 \mathrm{~m}^{2}$ & $2,88,000$ \\
\hline 10. & Cost of 25 Scheffler Dish for DTU plant & 72 Lakhs \\
\hline
\end{tabular}

\begin{tabular}{lll} 
11. & $\begin{array}{l}\text { Cost of water treatment, water storage, } \\
\text { piping and insulation etc. according to } \\
\text { MNRE standards }\end{array}$ & $\begin{array}{l}\text { of system } \\
\text { costi.e. 14.4 Lakhs }\end{array}$ \\
12. & Total cost for installation of DTU plant & 86.4 Lakhs \\
13. & $\begin{array}{l}\text { Subsidy available for two axes tracking } \\
\text { based Scheffler Dish }\end{array}$ & $6000 / \mathrm{m}^{2}$ \\
14. & Total subsidy available for $400 \mathrm{~m}^{2}$ & 24 Lakhs \\
15. & Final cost of installation for DTU plant & 62.4 Lakhs \\
16. Payback period & 2.84 years \\
\hline
\end{tabular}

\section{RESULT}

A Large portion of solar irradiation lost due to thermal energy loss, optical efficiency loss and cosine loss. Thermal energy losses can be reduce using effective insulation with glass wool at the receiver and pipes and with coating of blackboard paint on receiver front surface to increase absorption. Optical efficiency can be improved by routine cleaning of reflecting mirror and proper tracking system for daily and season tracking. The bar graph based on table 5.1.

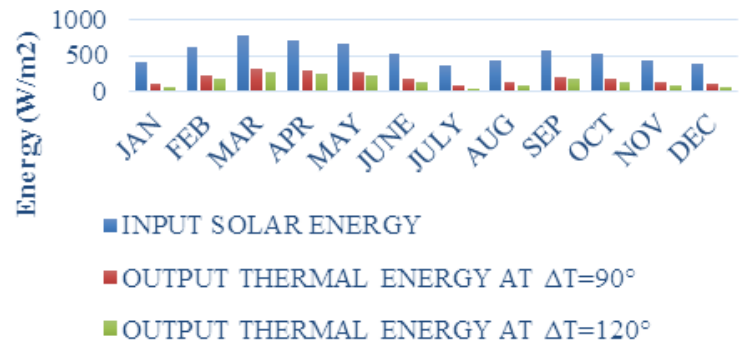

Figure 3. Variation in output thermal energy with $\Delta T$

Bar graph in Fig 3 describes the feasibility of steam cooking system for Delhi climatic conditions. Monthly requirement of mess remains constant whereas the thermal energy from sun varies month to month. It is based on the table 5.3 and 5.4 and shows maximum output for March to May and then decreases to minimum in July. From the figure it is concluded that almost half of thermal energy requirement can be fulfilled using such a system for cooking purpose.

\subsection{Payback period}

Table 5.Calculation for payback period is shown in tabular form with all necessary data 


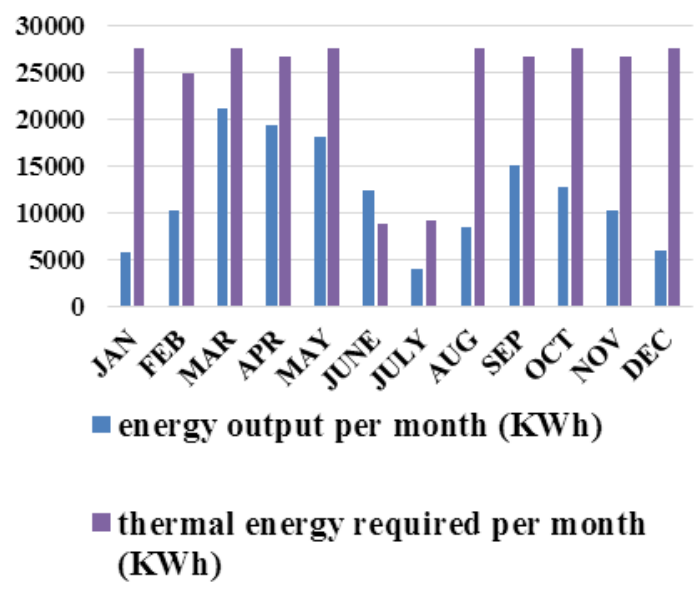

Figure 4. Monthly thermal energy requirement vs. DTU plant potential

Following graph in Fig 5 shows the efficiency variation at different temperature difference with highest efficiency at minimum temperature difference. For Delhi this graph shows the M shape curve with minimum in month of July. System will work efficiently in almost half of the year with the remaining time the backup system will be required to assist the steam cooking system. Comparison of efficiency of Parabolic Dish and Scheffler Dish with different temperature difference has shown in Fig 6. The curve for Scheffler decline more sharply as compared to Parabolic Dish. This is justified by the absence of cosine losses in Parabolic Dish as it always remains at the perpendicular position in respect of reflector surface. But the inherit drawback with Parabolic system for cooking is its moving focus with which a rigid steam distribution system cannot sustain. Payback period is calculated to 2.84 years without considering maintenance cost since it depends upon monitoring skills. Such cooking systems are working at Shantikunj (Haridwar), Shantivan (Mount Abu) and many other places in India due to proper maintenance.

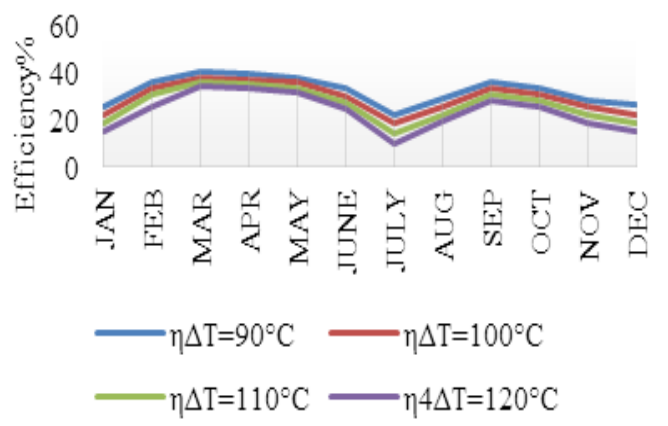

Fig. 5. Variation of efficiency of Scheffler Dish with month at different $\Delta T$

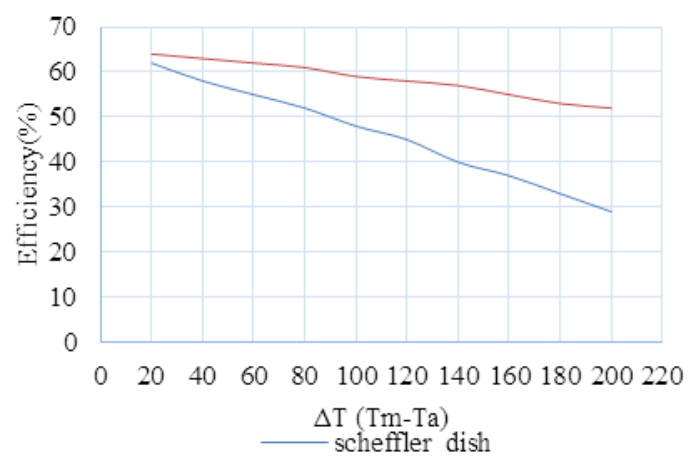

Figure 6 change in efficiency of Scheffler Dish and Parabolic Dish

\section{CONCLUSION}

In context of present work, a steam cooking system for DTU boys hostel mess is proposed with detail discussion. The study includes the energy requirement of mess, efficiency of Scheffler Dish in Delhi, number of Scheffler Dish required, emission reduction of $\mathrm{CO}_{2}$, and economic analysis. The outcomes of present study are given below.

Energy requirement of DTU boys hostel mess per annum $=288981 \mathrm{KWh}$

Efficiency of Scheffler Dish in Delhi at,

$$
\begin{aligned}
& \Delta \mathrm{T}_{1}=32 \% \\
& \Delta \mathrm{T}_{2}=29 \% \\
& \Delta \mathrm{T}_{3}=26.4 \% \\
& \Delta \mathrm{T}_{4}=23.4
\end{aligned}
$$

Energy required to cook one meal $=0.33 \mathrm{KWh}$

Number of Scheffler Dish required $=25$

Emission reduction of $\mathrm{CO}_{2}$ per annum $=95$ tonne

Cost of project bear by DTU $=62.4$ lakhs

Payback period $=2.84$ years

The efficiency decreases with increase in temperature difference, so it is beneficial to provide good insulation and operate the system at minimum possible temperature difference.

\section{REFERENCES}

[1] S. A. Kalogirou, Solar thermal collectors and applications, Progress in Energy and Combustion Science 30 (2004) 231-295.

[2] VDafle, N.N.Shinde., Design, Development \& Performance Evaluation Of Concentrating Monoaxial Scheffler Technology For Water Heating And Low Temperature Industrial Steam Application, International Journal of Engineering Research and Applications (IJERA) ISSN: 2248-9622, 2 (6) (2012) 848-852.

[3] A. C Kashyap., J. P Kesari., Feasible Study of a Solar Crematorium in India, IJISR 1 (4) 2014.

[4] M. R Phate., D. M Gadakari., S. S Acachut., A. D Tajne., Experimental Analysis of $2.7 \mathrm{~m}^{2}$ Scheffler Reflector, IJETT12

[5] S.Wu, L Xiao., Y.Cao, Y Li., A parabolic dish/AMTEC solar thermal power system and its performance evaluation, Applied Energy 87 (2010) $452-462$

[6] K.S Reddy., G Veershetty., Viability analysis of solar parabolic dish stand-alone power plant for Indian conditions, Applied Energy 102 (2013) 908-922. 